\title{
Sensors for Enhanced Detection of Acetone as a Potential Tool for Noninvasive Diabetes Monitoring
}

\author{
Artur Rydosz \\ Department of Electronics, AGH University of Science and Technology, 30-059 Krakow, Poland; \\ artur.rydosz@agh.edu.pl; Tel.: +48-12-617-25-94
}

Received: 16 June 2018; Accepted: 16 July 2018; Published: 16 July 2018

\begin{abstract}
Measurement of blood-borne volatile organic compounds (VOCs) occurring in human exhaled breath as a result of metabolic changes or pathological disorders is a promising tool for noninvasive medical diagnosis, such as exhaled acetone measurements in terms of diabetes monitoring. The conventional methods for exhaled breath analysis are based on spectrometry techniques, however, the development of gas sensors has made them more and more attractive from a medical point of view. This review focuses on the latest achievements in gas sensors for exhaled acetone detection. Several different methods and techniques are presented and discussed as well.
\end{abstract}

Keywords: exhaled acetone measurements; biomarkers; diabetes monitoring; gas sensors

\section{Introduction}

Exhaled human breath analysis has been developing for many years with the utilization of several different methods and techniques. However, the very beginning of breath analysis already started in ancient times, when Hippocrates taught his students how to use breath odor in order to identify patients with liver disease, uncontrolled diabetes, and even failing kidneys [1] There are a few additional pivotal moments in breath history that bring us to the present. In 1798, the odor of decaying apples in exhaled breath was described by John Gallo and 59 years later (1857), this odor was identified as acetone [2], which was used as a very first biomarker of diabetic coma. Over the years, exhaled acetone was underestimated, mostly because there were not any suitable devices to detect it in exhaled breath and correlate it with specific diseases, such as diabetes. Everything changed in early 70s, when Linus Pauling (1971) published a seminal article demonstrating analytical methodology used to identify approximately 250 compounds in breath [3]. This date is considered to be a starting point in the development of the exhaled breath analysis. Generally, methods used for detection of biomarkers in breath are based on spectrometry measurements, such as gas chromatography-mass spectrometry (GC-MS) [4,5], proton-transfer-reaction mass spectrometry (PTR-MS) [6,7], ion mobility spectrometry-mass spectrometry (IMS-MS) [8,9], selected-ion flow-tube mass spectrometry (SIFT-MS) [10,11], and so on. However, other techniques based on electronic noses [12,13] or single sensors became more attractive, due to the development of sensor technology, that is, miniaturization. The exhaled human breath consists almost of 3500 different volatile organic compounds (VOCs), and a single breath consists of around 500 various VOCs (Figure 1a), which are typically in the part per million (ppm), part per billion (ppb) range or part per trillion (ppt). The biomarkers present in the exhaled breath are used to indicate several diseases, such as lung cancer [14,15], asthma [16,17], chronic obstructive pulmonary disease (COPD) [18,19], breast cancer $[20,21]$, and diabetes $[22,23]$. The total number of diseases that can be detected or controlled by exhaled breath analysis is still unknown (Figure 1b). 


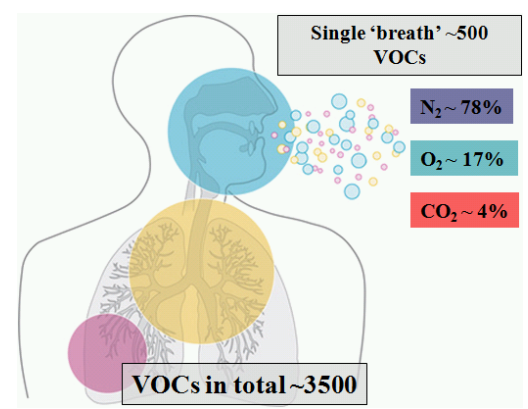

(a)

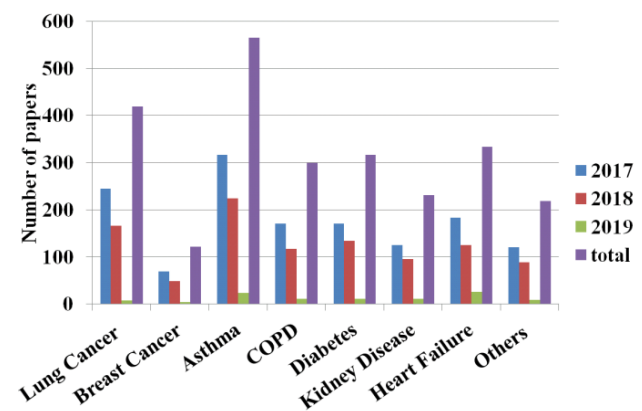

(b)

Figure 1. The exhaled breath: (a) general overview of the exhaled breath compounds; (b) number of papers in 2017-2019 related to exhaled breath analysis in term of possible disease indication. VOCs $=$ volatile organic compounds COPD = chronic obstructive pulmonary disease.

This paper focuses on the applications of exhaled acetone detection as a possible tool to monitor diabetes, as patients with diabetes tend to have higher acetone levels in their breath than healthy people [24]. Exhaled acetone is considered to be one of the biomarkers of this disease and the aim in future is to reduce the number of blood sugar measurements per day. The number of people with diabetes increases year by year. Based on the actual data provided by World Health Organization (WHO), 422 million adults have diabetes and 1.6 million deaths are directly attributed to diabetes each year [25]. The exhaled acetone is usually in the range of $0.2-1.8 \mathrm{ppm}$ for healthy people, and in the range of 1.25-2.5 ppm for people with diabetes [26]. Some references have shown that the acetone level can increase up to $25 \mathrm{ppm}$ for type-1 diabetes [27]. In order to measure such low gas concentrations in the laboratory, systems mentioned above have been applied, however, they can be utilized only in selected laboratories with well-qualified staff. The increasing number of diabetes patients who would like to control diabetes by a noninvasive method (the current practice is still based on blood sampling) has created a market for portable exhaled breath analyzers. Currently, the commercial available gas sensors for acetone detection work in the 50-5000 ppm, which is out of range for exhaled acetone levels [28]. One of the cheapest and very effective methods to increase the detection limit is by using a gas preconcentration structure $[29,30]$. In addition, scientists are carrying out research for developing a single gas sensor which could cover the exhaled acetone range [31] and, crucially, work at room temperature [32-35], and includes microwave-based [36,37] and optical-based sensors [38-40]. That makes the process noninvasive, real-time, and less expensive compared to the traditional medical diagnosis methods. In recent years, the topic has been a subject of many publications (Figure 2), therefore only the latest results will be shown and discussed in the following sections.

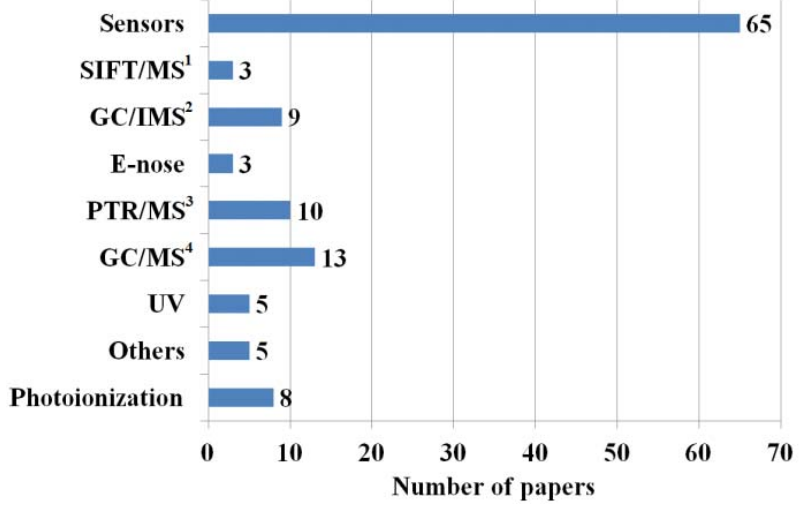

(a)

Figure 2. Cont. 


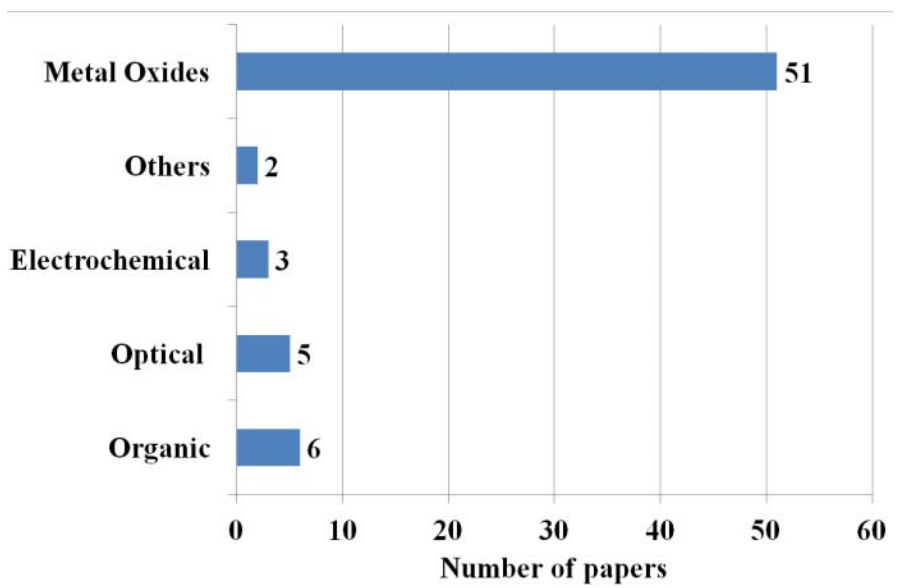

(b)

Figure 2. Search results of literature review (2017-2019) of the exhaled acetone analysis: (a) different methods: 1 Selected-ion flow-tube mass spectrometry; ${ }^{2}$ Gas Chromatograph-Ion Mobility Spectrometer; ${ }^{3}$ Proton-transfer-reaction mass spectrometry; ${ }^{4}$ Gas chromatograph-mass spectrometry (b) different materials used as receptors in sensor applications presented in papers.

\section{Major Achievements on Acetone Detection}

The latest results for exhaled acetone measurements will be presented and discussed. As mentioned in the Introduction, we can indicate two ranges of exhaled acetone concentration. The first one is related to the 'healthy' region, were the exhaled acetone is usually in the range of $0.2-1.8 \mathrm{ppm}$ and the second one is related to the 'diabetes' region, with an acetone range of 1.25-2.5 ppm or up to $25 \mathrm{ppm}$ [26]. Figure 3a shows the response of the sensor in both regions [41]. Based on the literature review, the 'healthy' and 'diabetes' regions are not strictly defined and various ranges can be considered. Generally, the diabetes patients tend to have a higher acetone concentration than healthy people, however, the acetone concentration can be related to many factors, such as comorbid diseases, diet, level of exercise, environmental pollution (especially in the workplace), and so on. The exhaled acetone concentration should always be correlated to blood glucose concentration and discussed with physicians, before being used as a single biomarker (Figure 2b) [26].

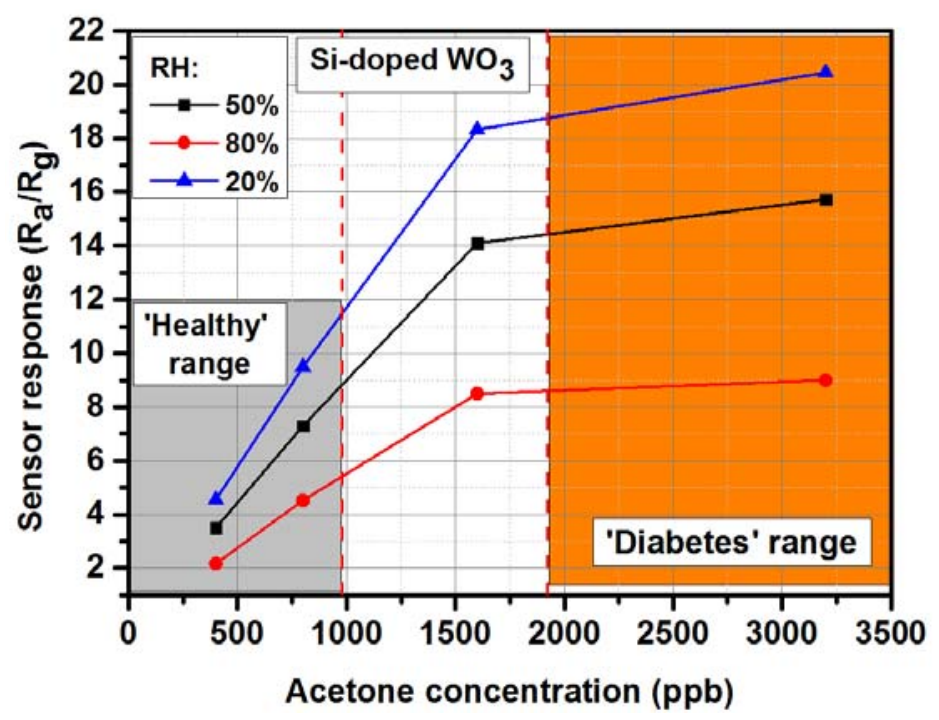

(a)

Figure 3. Cont. 


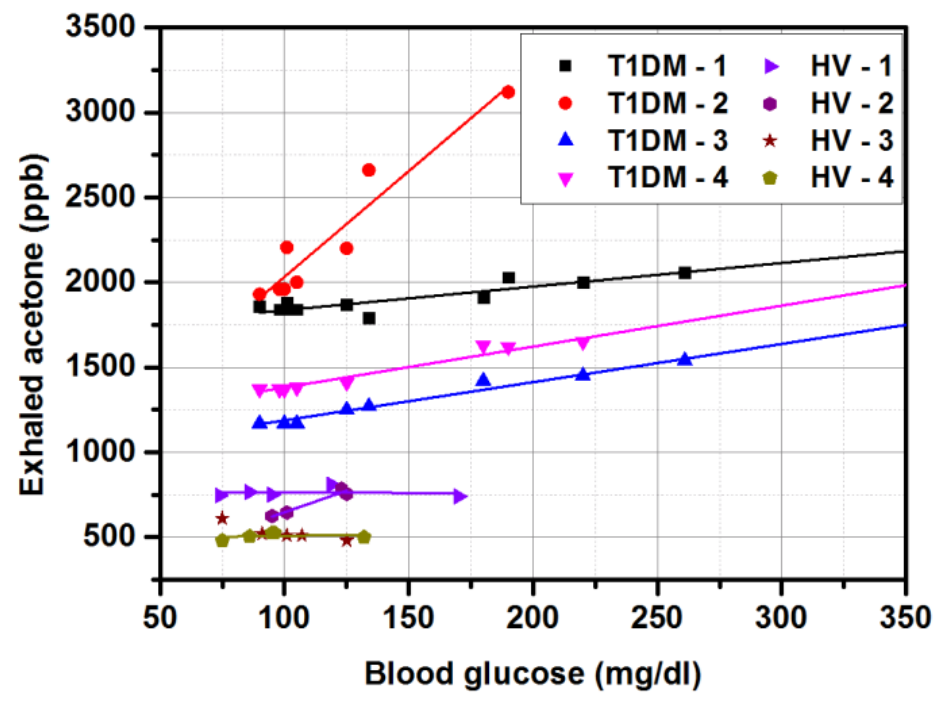

(b)

Figure 3. The 'healthy' and 'diabetes' regions in: (a) Si-doped $\mathrm{WO}_{3}$ acetone sensor (RH: Relative Humidity) [41]; (b) exhaled acetone concentration vs. blood glucose concentration for selected healthy volunteers (HV) and type-1 diabetes mellitus patients (T1DM) [26].

\subsection{Metal Oxides (MOXs) Based Sensors}

Various metal oxides have been investigated for acetone gas sensors, including single oxide or multi-oxides structures. The literature review for the latest achievements has shown some very promising results. Table 1 shows the summary of the literature review of the selected metal-oxide based sensors for acetone detection with special emphasis to exhaled acetone measurements in term of diabetes monitoring.

\subsection{1. $\mathrm{SnO}_{2}$-Based Sensors}

Among the various semiconducting metal oxides, tin oxides have been the most popular gas-sensing material so far investigated and used in practice. In the past decades, $\mathrm{SnO}_{2}$ is the most extensively studied material for gas-sensing applications, including enhanced acetone detection. Recently, Hu et al. [42] proved gas sensing properties of $\mathrm{NiO} / \mathrm{SnO}_{2}(\mathrm{p} / \mathrm{n})$ hierarchical structures towards acetone. The structures were fabricated by hydrothermal method and the gas sensing characteristics were obtained for acetone in the $210{ }^{\circ} \mathrm{C}-390{ }^{\circ} \mathrm{C}$ temperature range. The maximum response $R=R_{a} / R_{g}$ (where $R_{a}$ and $R_{g}$ are electrical resistance in air and in gas, respectively) equaled 20.18 measured at $300{ }^{\circ} \mathrm{C}$ under $50 \mathrm{ppm}$ of acetone [42]. Another group [43] have proposed acetone sensors based on $2 \mathrm{D} \mathrm{C}_{3} \mathrm{~N}_{4}-\mathrm{SnO}_{2}$. The sensor response was defined as $\mathrm{V}_{\mathrm{g}} / \mathrm{V}_{\mathrm{a}}$, where $\mathrm{V}_{\mathrm{g}}$ and $\mathrm{V}_{\mathrm{a}}$ are electrical voltages measured under exposure to gas and air, respectively. The highest responses were obtained at $380{ }^{\circ} \mathrm{C}$, for $20 \mathrm{ppm}$ acetone was around 11 and limit of detection was measured around $87 \mathrm{ppb}$ [43]. Kalidoss et al. [44] have presented the investigation results of $\mathrm{GO}-\mathrm{SnO}_{2}-\mathrm{TiO}_{2}$ ternary nanocomposite for acetone in diabetes mellitus patients' breath. The $\mathrm{GO}-\mathrm{SnO}_{2}-\mathrm{TiO}_{2}$ sensor exhibits superior gas sensing performance towards acetone in the range of $0.25 \mathrm{ppm}$ to $30 \mathrm{ppm}$ at $200{ }^{\circ} \mathrm{C}$, under exposure to $5 \mathrm{ppm}$ the response was $60\left(\mathrm{R}_{\mathrm{a}} / \mathrm{R}_{\mathrm{g}}\right)$ [44]. Tomer et al. [45] have presented the acetone detection using an indium loaded $\mathrm{WO}_{3} / \mathrm{SnO}_{2}$ nanohybrid sensor. The highest results were obtained for $\mathrm{In} / \mathrm{WO}_{3}-\mathrm{SnO}_{2}(2 \mathrm{wt} \% \mathrm{In})$, the response $\left(\mathrm{R}_{\mathrm{a}} / \mathrm{R}_{\mathrm{g}}\right)$ was 66.5 for $50 \mathrm{ppm}$ of acetone at $200{ }^{\circ} \mathrm{C}$ with detection limit around 1 ppm [45]. Asgari et al. [46] have discussed the acetone sensing characteristics of $\mathrm{SnO}_{2}$ decorated $\mathrm{SiO}_{2}$ sensors in a wide range of temperatures $\left(70-420{ }^{\circ} \mathrm{C}\right)$ and concentrations (0.5-5 ppm). The highest results were obtained for $80 \mathrm{wt} \% \mathrm{SnO}_{2} / \mathrm{SiO}_{2}$ at $270{ }^{\circ} \mathrm{C}$ under $300 \mathrm{ppm}$ of acetone. The response was defined as $S=R_{a} / R_{g}-1$ and for above conditions was around 2193.7. 
In the exhaled acetone concentrations range, the response was $1.4,9.4,24.1$, and 37.5 under exposure to $0.5,1,2.5$, and 5 ppm acetone, respectively [46].

\subsection{2. $\mathrm{WO}_{3}$-Based Sensors}

One of the very common metal oxides used for exhaled acetone detection is the tungsten oxide $\left(\mathrm{WO}_{3}\right)$. It exhibits a typical n-type conducing behavior with a high catalytic behavior both in oxidation and reduction reaction on its surface. There are numerous papers presenting the low concentration acetone detection with utilization of the $\mathrm{WO}_{3}$-based sensors, however, in this paper only the latest results will be shown, including results owned by the author. Very recently, Li et al. [47] have presented the investigation results of $\mathrm{Ru}$-loaded $\mathrm{WO}_{3}$ nanoparticles. The sensor response to acetone was promoted by more than 5 times for Ru-loaded sensors comparing with neat $\mathrm{WO}_{3}$ with low detection limit down to $0.5 \mathrm{ppm}$. The highest response $\left(\mathrm{R}_{\mathrm{a}} / \mathrm{R}_{\mathrm{g}}\right)$ was obtained for $1 \mathrm{wt} \% \mathrm{Ru}$ and it was around 7.3 at $300{ }^{\circ} \mathrm{C} / 1.5 \mathrm{ppm}$ [47]. Kim et al. [48] have proposed acetone sensors based on $\mathrm{WO}_{3}$ nanofibers (NFs) with hierarchically interconnected porosity (HP_WO $3 \mathrm{NFs}$ ) with 10.80 response $\left(\mathrm{R}_{\mathrm{a}} / \mathrm{R}_{\mathrm{g}}\right)$ at $1 \mathrm{ppm}$ of acetone and high humidity atmosphere $(90 \%$ Relative Humidity $(\mathrm{RH}))$, which constitutes one of the crucial parameters in detection of biomarkers in exhaled human breath [48]. Chen et al. [49] have shown the acetone sensing characteristics for gravure-printed $\mathrm{WO}_{3} / \mathrm{Pt}$-decorated rGO nanosheets composites. The highest response was 12.2 to $10 \mathrm{ppm}$ at $200{ }^{\circ} \mathrm{C}$ [49]. Shen at al. [50] have shown the selective acetone sensor based on iron and carbon codoped $\mathrm{WO}_{3}$ with hierarchical walnut-like microstructure. The maximum response was obtained for 0.992 at $\% \mathrm{Fe} / \mathrm{WO}_{3}\left(\sim 17 \mathrm{R}_{\mathrm{a}} / \mathrm{R}_{\mathrm{g}}\right)$ at $300{ }^{\circ} \mathrm{C}$ to $10 \mathrm{ppm}$ of acetone [50]. The main goal of the investigations carried out by the author is to develop the device to analyze the exhaled acetone concentrations based on the metal oxides' thin films. The gas sensor substrates array was developed with Low Temperature Cofired Ceramics (LTCC) technology. Figure 4a shows the view of such array, and more details can be found elsewhere [51]. The author et al. [41] has developed the Si-doped $\mathrm{WO}_{3}$ thin films by glancing angle DC magnetron sputtering technique for the acetone detection (Figure $3 a)$. The highest response $\left(R_{a} / R_{g}\right)$ was obtained for sensors deposited and annealed in $300{ }^{\circ} \mathrm{C}$ and it was 22 under exposure to $1 \mathrm{ppm}$ of acetone at $425^{\circ} \mathrm{C}$ and $50 \% \mathrm{RH}$. Limit of detection was $0.16 \mathrm{ppm}$, which makes these sensors able to work in exhaled acetone detectors [41].

\subsection{3. $\mathrm{Fe}_{\mathrm{x}} \mathrm{O}_{\mathrm{y}}$-Based Sensors}

Three oxygen compounds of iron are very common: $\mathrm{FeO}, \mathrm{Fe}_{2} \mathrm{O}_{3}$, and $\mathrm{Fe}_{3} \mathrm{O}_{4}$, whereas the $\mathrm{Fe}_{2} \mathrm{O}_{3}$ was generally studied in gas-sensing applications. The main limitation for $\mathrm{Fe}_{2} \mathrm{O}_{3}$-based gas sensors is operating temperature $\left(450{ }^{\circ} \mathrm{C}-1075^{\circ} \mathrm{C}\right)$, as such temperature creation is difficult on gas sensor substrates, such as silicon. However, recently Wang et al. [52] have presented the acetone sensor working at low concentrations $\sim 1 \mathrm{ppm}$ and lower temperatures $\sim 160^{\circ} \mathrm{C}$, which is based on $\mathrm{NiFe}_{2} \mathrm{O}_{4}$ nanocubes. The maximum response $\mathrm{R}=\mathrm{R}_{\mathrm{g}} / \mathrm{R}_{\mathrm{a}}$ was $30.4\left(160{ }^{\circ} \mathrm{C} / 200 \mathrm{ppm}\right)$ and around 12 under $50 \mathrm{ppm}$ of acetone $\left(160{ }^{\circ} \mathrm{C}\right)$ [52]. This significant detection of acetone is a noteworthy point and probably this may draw larger attention in future.

\subsection{4. $\mathrm{TiO}_{2}$-Based Sensors}

Among the different oxides of titanium most thoroughly studied is $\mathrm{TiO}_{2}$, which exhibits n-type behavior. Its gas-sensing properties are highly related to its composition, hence many scientific groups are presently working on this material with special emphasis on its different nanostructures. Recently, Park [53] has presented the investigation results of $\mathrm{TiO}_{2}$ nanoparticles functionalized $\mathrm{In}_{2} \mathrm{O}_{3}$ nanowires for exhaled acetone measurements. The measurements were carried out as a function of $0.1,0.2,0.5,1$, 2,5 , and $10 \mathrm{ppm}$ acetone at $250^{\circ} \mathrm{C}$ and the responses $\left(\mathrm{R}_{\mathrm{g}} / \mathrm{R}_{\mathrm{a}}\right)$ equaled $4.07,4.83,6.17,8.8,12.25,20.55$, and 33.34, respectively. The detection mechanism was clearly discussed, which makes this material very attractive for commercial use [53]. 


\subsection{5. $\mathrm{In}_{2} \mathrm{O}_{3}$-Based Sensors}

Cubing indium oxide $\left(\operatorname{In}_{2} \mathrm{O}_{3}\right)$ has been widely used in the microelectronic field, including gas sensors. Gas-sensing characteristics of $\mathrm{In}_{2} \mathrm{O}_{3}$-based sensors depend strongly on the condition of their preparation, which determine the atomic structure formation, phase composition, and indium electronic states in the sensing material [31]. Recently, Liu et al. [54] have presented the results of Sb-doped $\operatorname{In}_{2} \mathrm{O}_{3}$ microstructures towards acetone exhibition. The peony-like hierarchical flowers with different $\mathrm{Sb}$ contents have been fabricated via the oxidization conversion of hydrothermally synthesized $\operatorname{In}_{2} S_{3}$ precursors. The maximum response equals $64.3\left(R_{a} / R_{g}\right)$ to acetone with $50 \mathrm{ppm}$ at $240{ }^{\circ} \mathrm{C}$ and was obtained for $2 \mathrm{~mol} \% \mathrm{Sb}$ composition. The developed sensor has fast response/recovery time $(8 / 27 \mathrm{~s})$, and long-term stability characteristics towards acetone gas. Further investigations are needed to determine the selectivity to other VOCs present in human breath.

\subsubsection{ZnO-Based Sensors}

Zinc oxide $(\mathrm{ZnO})$ is a very promising semiconducting (naturally n-type) metal oxide for gas-sensing applications. It is well studied since it was used as early as 1960s and the gas-sensing mechanism is well understood. However, a novel composition of $\mathrm{ZnO}$ nanostructures doped or decorated with other metals are still under investigation, in terms of enhanced acetone detection at lower concentrations. Recently, Wongrat et al. [55] have shown the acetone sensors based on $\mathrm{ZnO}$ nanostructures decorated with $\mathrm{Pt}$ and $\mathrm{Nb}$. The maximum sensor response of sensors based on $\mathrm{ZnO}: \mathrm{Pt}$ and $\mathrm{ZnO}: \mathrm{Nb}$ was found upon exposure toward acetone vapor at $1000 \mathrm{ppm}$ concentration $\left(400{ }^{\circ} \mathrm{C}\right)$ with the value of 188.0 and 224.0, respectively [55]. The main disadvantage of $\mathrm{ZnO}: \mathrm{Pt} / \mathrm{ZnO}: \mathrm{Nb}$-based sensors in comparison to other MOX-based acetone sensors discussed in this review is still higher operating temperature.

\subsubsection{CuO-Based Sensors}

Copper forms compounds in the oxidation states +1 and +2 in its normal chemistry, however, mostly $\mathrm{CuO}$ phase is reported as a gas-sensitive material with p-type semiconducting property. Very recently, the author et al. [56] has demonstrated the gas-sensing characteristics of Cr-doped $\mathrm{CuO}$ (Figure $4 \mathrm{~b}$ ), where the highest response was obtained at $450{ }^{\circ} \mathrm{C}(3.2 \mathrm{ppm}$ of acetone) with limit of detection $\sim 0.4 \mathrm{ppm}$ [56]. The developed sensor, on one hand, exhibits high sensitivity to acetone at lower concentrations but, on the other hand, the operating temperature is very high in comparison to the latest achievement in such field. Further investigations are required to developed $\mathrm{CuO}$ nanostructures with lower operating temperatures.

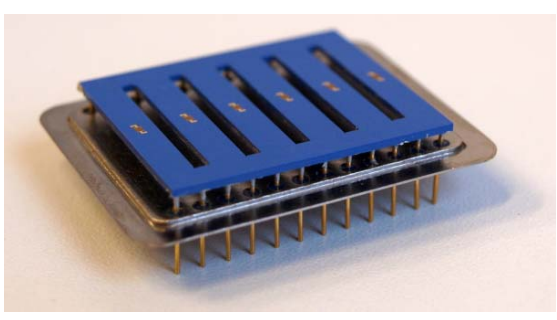

(a)

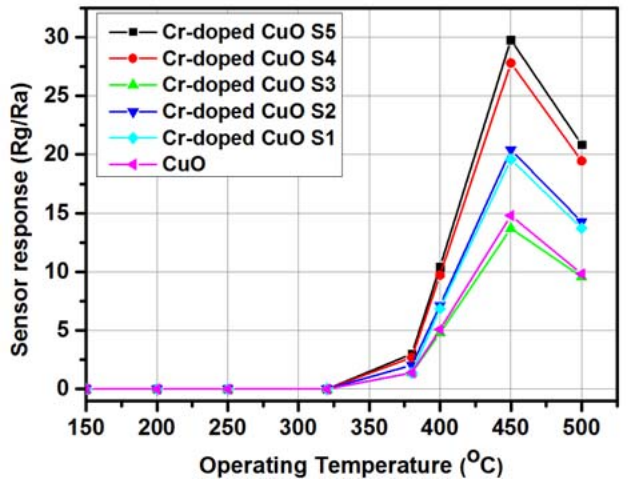

(b)

Figure 4. (a) Low Temperature Cofired Ceramics (LTCC) gas sensor array [55] (b) The acetone gas sensing characteristics of developed $\mathrm{Cr}$-doped $\mathrm{CuO}$ sensors under exposure to $3.2 \mathrm{ppm}$ of acetone for various operating temperatures [56]. 
Table 1. Summary of the literature review of the selected metal-oxide based sensors for acetone detection with special emphasis to exhaled acetone measurements in term of diabetes monitoring.

\begin{tabular}{|c|c|c|c|c|c|}
\hline Material & Max. Response & Temp. $\left({ }^{\circ} \mathrm{C}\right)$ & $\begin{array}{c}\text { Acetone } \\
(\mathrm{ppm})\end{array}$ & $\operatorname{LOD}^{1}$ (ppm) & Reference \\
\hline $\mathrm{NiO} / \mathrm{SnO}_{2}$ & $20.18 \mathrm{R}_{\mathrm{a}} / \mathrm{R}_{\mathrm{g}}{ }^{2}$ & 300 & 50 & 0.01 & [42] \\
\hline $\mathrm{NiFe}_{2} \mathrm{O}_{4}$ & $30.4 \mathrm{R}_{\mathrm{g}} / \mathrm{R}_{\mathrm{a}}$ & 160 & 200 & 0.52 & [52] \\
\hline $\mathrm{SnO}_{2} / \mathrm{SiO}_{2}$ & $2193.7 R_{a} / R_{g}-1$ & 270 & 300 & 0.5 & [46] \\
\hline $\mathrm{TiO}_{2} / \mathrm{In}_{2} \mathrm{O}_{3}$ & $33.34 \mathrm{R}_{\mathrm{g}} / \mathrm{R}_{\mathrm{a}}$ & 250 & 10 & 0.1 & [53] \\
\hline $\mathrm{Sb} / \mathrm{In}_{2} \mathrm{O}_{3}$ & $64.3 \mathrm{R}_{\mathrm{a}}^{\circ} / \mathrm{R}_{\mathrm{g}}$ & 240 & 50 & - & [54] \\
\hline $\mathrm{C}_{3} \mathrm{~N}_{4}-\mathrm{SnO}_{2}$ & $11 \mathrm{~V}_{\mathrm{g}} / \mathrm{V}_{\mathrm{a}}^{3}$ & 380 & 20 & 0.087 & [43] \\
\hline GO-SnO $2-\mathrm{TiO}_{2}$ & $60 \mathrm{R}_{\mathrm{a}} / \mathrm{R}_{\mathrm{g}}$ & 200 & 5 & 0.25 & [46] \\
\hline $\mathrm{ZnO}: \mathrm{Pt}$ & $188.0 \mathrm{R}_{\mathrm{a}} / \mathrm{R}_{\mathrm{g}}$ & 400 & 1000 & 1 & [55] \\
\hline $\mathrm{ZnO}: \mathrm{Nb}$ & $224.0 \mathrm{R}_{\mathrm{a}} / \mathrm{R}_{\mathrm{g}}$ & 400 & 1000 & 1 & [55] \\
\hline $\mathrm{Pd} / \mathrm{LaFeO}_{3}$ & $1.19 \mathrm{R}_{\mathrm{g}} / \mathrm{R}_{\mathrm{a}}^{\circ}$ & 200 & 1 & 1 & [57] \\
\hline $\mathrm{Pt}_{0.3} \mathrm{Au}_{0.7}-\mathrm{In}_{2} \mathrm{O}_{3}$ & $40 \mathrm{R}_{\mathrm{g}} / \mathrm{R}_{\mathrm{a}}$ & 160 & 50 & 0.3 & [58] \\
\hline $\mathrm{CuFe}_{2} \mathrm{O}_{4} / \alpha-\mathrm{Fe}_{2} \mathrm{O}_{3}$ & $14 R_{a} / R_{g}$ & 275 & 70 & 0.1 & [59] \\
\hline $\mathrm{ZnO}-\mathrm{Fe}_{3} \mathrm{O}_{4}$ & $47 \mathrm{R}_{\mathrm{a}} / \mathrm{R}_{\mathrm{g}}$ & 475 & 50 & 0.15 & {$[60]$} \\
\hline $\mathrm{ZnCo}_{2} \mathrm{O}_{4}$ & $38 \mathrm{R}_{\mathrm{g}} / \mathrm{R}_{\mathrm{a}}$ & 200 & 500 & 0.5 & [61] \\
\hline $\mathrm{Co}_{3} \mathrm{O}_{4}$ & $17 R_{g} / R_{a}$ & 111 & 1000 & - & {$[62]$} \\
\hline $\mathrm{Co}_{1-\mathrm{x}} \mathrm{Zn}_{\mathrm{x}} \mathrm{Fe}_{2} \mathrm{O}_{4}$ & $-112 \mathrm{mV}$ & 650 & 50 & 0.3 & [63] \\
\hline $\mathrm{TiO}_{2}$ & $25.97 \mathrm{R}_{\mathrm{a}} / \mathrm{R}_{\mathrm{g}}$ & 370 & 500 & - & {$[64]$} \\
\hline $\mathrm{Ru} / \mathrm{WO}_{3}$ & $7.3 \mathrm{R}_{\mathrm{a}} / \mathrm{R}_{\mathrm{g}}{ }^{\circ}$ & 300 & 1.5 & 0.5 & [47] \\
\hline $\mathrm{WO}_{3} \mathrm{NFs}$ & $90 R_{a} / R_{g}$ & 350 & 5 & 0.4 & [48] \\
\hline $\mathrm{WO}_{3} / \mathrm{Pt}-\mathrm{GNs}$ & $12 R_{a} / R_{g}^{0}$ & 200 & 10 & 1 & [49] \\
\hline $\mathrm{In} / \mathrm{WO}_{3}-\mathrm{SnO}_{2}$ & $66.5 \mathrm{R}_{\mathrm{a}} / \mathrm{R}_{\mathrm{g}}$ & 200 & 50 & 1 & [45] \\
\hline
\end{tabular}

\subsection{Ultraviolet Illumination-Assisted Sensors}

One of the promising methods to increase the limit of detection for metal oxide sensors is the ultraviolet illumination during the gas detection. Yang et al. [65] have presented the experimental results of a gas sensor based on monolayer graphene with UV illumination $(370 \mathrm{~nm})$. The obtained results have been 10 times higher than without illumination, with limit of detection around $600 \mathrm{ppb}$ of acetone at room temperature [65]. The same group [66] have been testing the sensor in the 100-1000 ppb range with two different electrodes, spacing dimensions: $50 \mu \mathrm{m}$ and $400 \mu \mathrm{m}$ with and without UV. The highest resistance changes were measured for $400 \mu \mathrm{m}$ with UV and it was $1.8 \%$ for $1000 \mathrm{ppb}$ and $0.3 \%$ for $100 \mathrm{ppb}$ [66]. Zhang et al. [67] have shown the low concentration of acetone gas sensing properties of $3 \mathrm{wt} \% \mathrm{Pd}$-doped $\mathrm{SmCo}_{x} \mathrm{Fe}_{1-\mathrm{x}} \mathrm{O}_{3}$ nanocrystalline powders under $\mathrm{UV}$ light illumination. The UV light $\left(365 \mathrm{~nm}\right.$ ) allows the reduction of the operating temperature from $220^{\circ} \mathrm{C}$ to $160{ }^{\circ} \mathrm{C}$ with an improvement of response, from 13.86 (without UV) to 15.85 (with UV) for 1 ppm of acetone. Limit of detection for such an application was around $0.2 \mathrm{ppm}$ [67].

\subsection{Optical Applications}

Optical measurements of exhaled acetone concentrations, as well, can be a very attractive method for precise analysis, however, the nature of optical measurements makes it less portable than other methods, especially MOX sensors. Ye et al. [68] have presented a highly sensitive acetone biochemical gas sensor based on a flow-cell with nicotinamide adenine dinucleotide (NADH)-dependent secondary alcohol dehydrogenase (S-ADH) immobilized membrane onto a fiber-optic. The system utilizes an UV LED with peak commission of $335 \mathrm{~nm}$; such a system was able to identify acetone from $20 \mathrm{ppb}$ to $5300 \mathrm{ppb}$, which covers the healthy and diabetes region of exhaled acetone. Moreover, the response time was between $35-70 \mathrm{~s}$, which makes such a system very attractive as a noninvasive tool for screening tests, even if portability is a little bit lower in comparison with other systems [68]. Teshima et al. [69] 
have presented the LED-based photometric method with GaN-based LEDs with emission centered at $465 \mathrm{~nm}$ for acetone detection. The detection limit of such a system was $14 \mathrm{ppb}$ [69].

\subsection{Preconcentration for Exhaled Acetone Detection}

The concentration level of biomarkers in exhaled human breath is in the range of ppt (part per trillion) to ppm (part per million), which is out of range for commercial available gas sensors. There are two main ways to detect such an amount of compounds: to develop a gas sensor or gas sensor array with a suitable limit of detection or to use a preconcentrator to preconcentrate biomarkers in samples before the analysis. Both ways are being developed in parallel by researchers, however, gas sensors in conjunction with preconcentrators give the best results. The preconcentration technique is well known in chromatography where the separation column is filled with adsorbent molecules. The same mechanism is mostly applied for preconcentrators for exhaled biomarkers. In recent years several various examples of utilization of the preconcentration technique was presented, such as: two-step preconcentration in order to reduce the humidity level in exhaled samples [70], in-needle preconcentration [71], preconcentration with surface acoustic wave (SAW) sensors [72], preconcentrator with micropillars fabricated from a silicon wafer [73], micropreconcentrator in silicon-glass technology (Figure 5a) [74,75], and a unique solution developed by the author-micropreconcentrator in LTCC (Low Temperature Cofired Ceramics) for a low level acetone detection (Figure 5b) [76,77] in conjunction with mass spectrometry [78] and sensor array [26] for exhaled breath acetone detection.

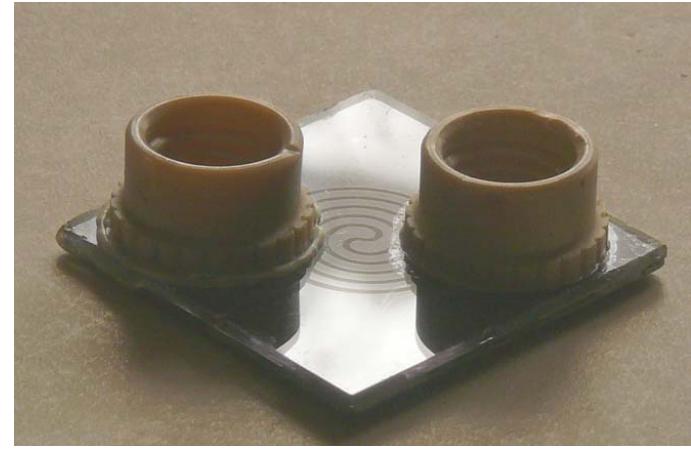

(a)

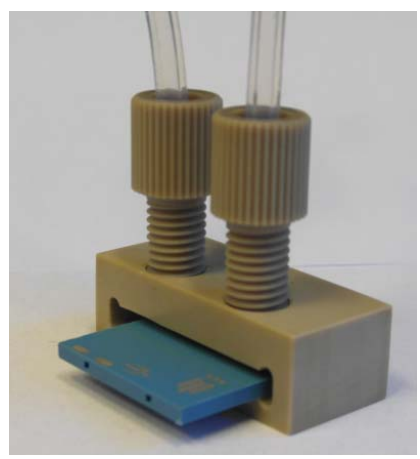

(b)

Figure 5. The photographs of the micropreconcentrator structures developed by the author for exhaled acetone measurements (a) in silicon-glass technology (b) in low temperature cofired technology (LTCC) with assembled gas ports.

\subsection{Organic-Based Gas Sensing Materials to Acetone}

The organic-based acetone sensors have several advantages, however, two of them should be highlighted. First of all, they always work at room temperature. Additionally, the gas sensing materials based on organic compounds can be 'designed' to detect selected compounds with very low cross sensitivity to other compounds, which is a crucial issue in exhaled breath analysis, where a single breath consists of around 500 different VOCs. Very recently, Chuang et al. [79] have presented an acetone sensor based on cylindrical nano-pore structures, which enhanced the sensitivity down to ppb levels. The sensing performance was demonstrated both in pure nitrogen and ambient air. The sensor constructed with poly[(9,9-dioctylfluorenyl-2,7-diyl)-co-(4,4-(N-(4-sec-butylphenyl)diphenylamine))] (TFB) exhibited a $5 \%$ sensing response to $300 \mathrm{ppb}$ of ACETONE in ambient air [79]. The author has some experience in organic-based acetone gas sensors, that is, in Reference [36] the novel comb copolymer phthalocyanine thin films deposited on microwave gas sensor substrate designed in stripline technology were investigated [36], and further expanded the microwave measurement system as it was shown in Reference [37]. 


\subsection{Devices}

There are many potential advantages of breath tests over conventional laboratory tests, for example, noninvasive, pain-less, easy to use, real-time measurements, and so on. However, they have not yet been applied into clinical practice, possibly because there are no commercially available devices. Since 2009, several groups have shown their own prototypes for exhaled breath monitoring, such as: Wang and Sahay presented a prototype breath acetone analyzer using pulsed-CRDS at $266 \mathrm{~nm}$ [80]; in 2011 Schwoebel at al. [81] presented the experimental setup of the device based on on-line PTR-MS and off-line SPME-GC-MS (SPME: Solid-Phase Microextraction) methods; and in 2014 Toshiba Corp. [82] announced that they had developed a prototype of a compact breath analyzer that can detect a wide range of trace gases in exhaled breath. Currently, the author has fabricated the exhaled acetone detector. Figure 6a shows the schematic view of the device, where the preconcentration unit is utilized by one of the micropreconcentrator structures shown in Figure 5, and gas sensor array is based on the array of sensors presented in Figure 4. Figure $6 \mathrm{~b}$ shows the photograph of the device, which has already been verified in laboratory conditions and is awaiting a clinical test (patent pending). Most of the developed devices are still under laboratory verification or undergoing clinical testing, which are crucial before targeting the market.

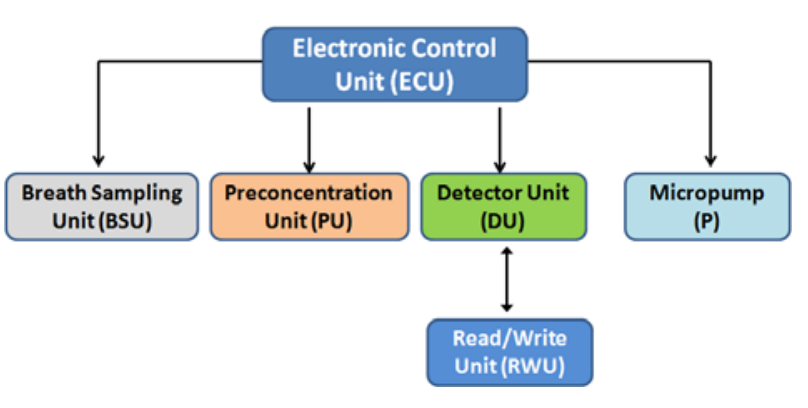

(a)

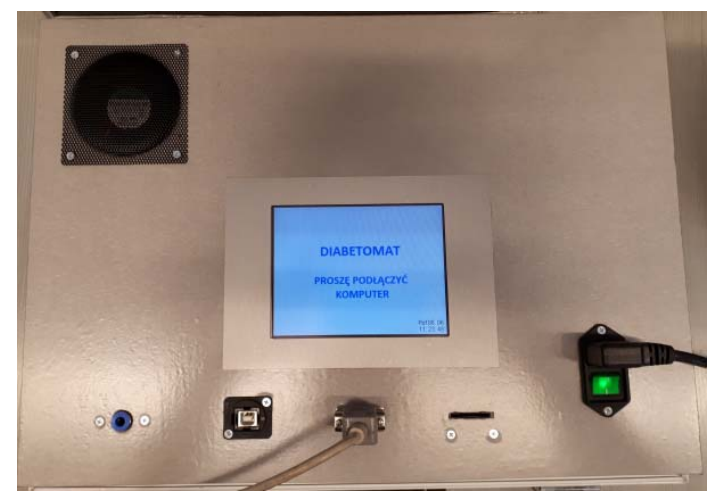

(b)

Figure 6. "Diabetomat" developed by the author: (a) schematic view of the device; (b) photograph of fabricated device. Patent pending.

\section{Conclusions and Future Perspectives}

As already presented, the exhaled acetone measurements can be applied as a potential tool for rapid diabetes detection in screening tests or for diabetes monitoring based on the relation between the exhaled acetone concentration and the glucose concentration in blood. The synergies between medicine and engineering in the detection of VOCs have the potential to revolutionize the way we control human health. The exhaled breath can be considered as a "breath-print" similar to a finger-print, which is commonly used as a personalized key. Moreover, the exhaled acetone is considered also as a biomarker in heart failures (HF). It is hypothesized that in patients admitted with acute decompensated hearth failure (ADHF) serial changes in exhaled acetone and pentane are associated with clinical indices of HF disease severity and diuretic response $[83,84]$, which means that exhaled acetone detection becomes more and more attractive for physicians. However, the market is still waiting for devices able to detect the low amount of biomarkers, such as acetone. The breath acetone sensor development in the next few years should focus on the fabrication process to deliver to market a final device to precisely and reproducibly collect exhaled breath and perform the analysis, and should consider the variations in the breath cycle (e.g., way in which human subjects breathe during the measurements) and the background level of the interfering compounds (e.g., ambient air contamination is an issue). Long-term tests need to be carried out for all referred detection techniques in order to be one-hundred percent sure that 
obtained results are relevant [85]. Multidisciplinary collaboration is the only way to achieve such a goal—development of fully noninvasive devices for detection and evaluation of disease states.

Funding: The work was financial supported by the National Centre for Research and Development under LIDER/252/L-6/NCBR/2015.

Conflicts of Interest: The author declares no conflict of interest.

\section{References}

1. Phillips, M. Breath test in medicine. Sci. Am. 1992, 267, 74-79. [CrossRef] [PubMed]

2. Crofford, O.B.; Mallard, R.E.; Winton, R.E.; Rogers, N.L.; Jackson, J.C.; Keller, U. Acetone in breath and blood. Trans. Am. Clin. Climatol. Assoc. 1977, 88, 128-139. [PubMed]

3. Pauling, L.; Robinson, A.B.; Teranishi, R.; Cary, P. Quantitative analysis of urine vapor and breath by gas-liquid partition chromatography. Proc. Natl. Acad. Sci. USA 1971, 68, 2374-2376. [CrossRef] [PubMed]

4. Deng, C.; Zhang, J.; Yu, X.; Zhang, W.; Zhang, X. Determination of acetone in human breath by gas chromatography-mass spectrometry and solid-phase microextraction with on-fiber derivatization. J. Chromatogr. B 2004, 810, 269-275. [CrossRef]

5. Lubes, G.; Goodarzi, M. GC-MS based metabolomics used for the identification of cancer volatile organic compunds as biomarkers. J. Pharm. Biomed. Anal. 2018, 147, 313-322. [CrossRef] [PubMed]

6. Fedrigo, M.; Hoeschen, C.; Oeh, U. Multidimensional statistical analysis of PTR-MS breath samples: A test study on irradiation detection. Int. J. Mass Spectrom. 2010, 295, 13-20. [CrossRef]

7. Righettoni, M.; Schmid, A.; Amann, A.; Pratsinis, S.E. Correlations between blood glucose and breath components from portable gas sensors and PTR-TOF-MS. J. Breath Res. 2013, 7, 037110. [CrossRef] [PubMed]

8. Lapthorn, C.; Pullen, F.; Chowdhry, B.Z. Ion mobility spectrometry-massspectrometry (IMS-MS) of small molecules: Separating and assigning structures to ions. Mass Spectrom. Rev. 2013, 32, 43-71. [CrossRef] [PubMed]

9. Szymanska, E.; Tinnevelt, G.H.; Brodrick, E.; Williams, M.; Davies, A.N.; van Manen, H.-J.; Buydens, L.M.C. Increasing conclusiveness of clinical breth analysis by improved baseline correction of multi capillary column-ion mobility spectrometry (MCC-IMS) data. J. Pharm. Biomed. Anal. 2016, 127, 170175. [CrossRef] [PubMed]

10. Michalcikova, R.B.; Dryahina, K.; Spanel, P. SIFT-MS quantification of several breath biomarkers of inlammatory bowel disease, IBD; A detailed study of the ion chemistry. Int. J. Mass Spectrom. 2016, 396, 35-41. [CrossRef]

11. Smith, D.; Spanel, P. Direct, rapid quantitative analyses of BVOCs using SIFT-MS and PTR-MS obviating sample collection. TrAC 2011, 30, 945-959. [CrossRef]

12. Saidi, T.; Zaim, O.; Moufid, M.; Bari, N.E.; Ionescu, R.; Bouchikhi, B. Exhaled breath analysis using electronic nose and gas chromatography-mass spectrometry for non-invasive diagnosis of chronic kidney disease, diabetes mellitus and healthy subjects. Sens. Actuators B 2018, 257, 178-188. [CrossRef]

13. Van de Goor, R.; van Hooren, M.; Dingemans, A.-M.; Kremer, B.; Kross, K. Training and Validating a Portable Electronic Nose for Lung Caner Screening. J. Thorac. Oncol. 2018, 13, 676-681. [CrossRef] [PubMed]

14. Saalberg, Y.; Wolff, M. VOC breath biomarkers in lung cancer. Clin. Chim. Acta 2016, 459, 5-9. [CrossRef] [PubMed]

15. Chang, J.-E.; Lee, D.-S.; Ban, S.-W.; Oh, J.; Jung, M.Y.; Kim, S.-H.; Park, S.J.; Persaud, K.; Jheon, S. Analysis of volatile organic compounds in exhaled human breath for lung cancer diagnosis uisng a sensor system. Sens. Actuators B 2018, 255, 800-807. [CrossRef]

16. Bos, L.D.; Sterk, P.J.; Fowler, S.J. Breathomics in the setting of asthma and chronic obstructive pulmonary disease. J. Allergy Clin. Immunol. 2016, 138, 970-976. [CrossRef] [PubMed]

17. Hanania, N.A.; Pharm, M.M.; Jain, N. Measurement of fractional exhaled nitric oxide in real-world clinical practice alters asthma treatment decisions. Ann. Allergy Asthma Immunol. 2018, 120, 414-418. [CrossRef] [PubMed]

18. Anders, C.; Rømhild, D.J.; Ingrid, T.; Jørgen, V.; Jan, B. A systematic review of breath analysis and detection of volatile organic compounds in COPD. J. Breath Res. 2016, 10, 034002. [CrossRef] 
19. Bregy, L.; Nussbaumer-Ochsner, Y.; Sinues, P.M.-L.; Garcia-Gomez, D.; Suter, Y.; Gaisl, T.; Stebler, N.; Gaugg, M.T.; Kohler, M.; Zenobi, R. Real-time mass spectrometric identification of metabolites characteristic of chronic obstructive pulmonary disease in exhaled breath. Clin. Mass Spectrom. 2018, 7, 29-35. [CrossRef]

20. Herman-Saffar, O.; Boger, Z.; Libson, S.; Lieberman, D.; Gonen, R.; Zeiri, Y. Early non-invasive detection of breast cancer using exhaled breath and urine analysis. Comput. Biol. Med. 2018, 96, 227-232. [CrossRef] [PubMed]

21. LI, H.; Peng, Y.; Duan, Y. Diagnosis of breast cancer based on breath analysis: An emerging method. Crit. Rev. Oncol. Hematol. 2013, 87, 28-40. [CrossRef] [PubMed]

22. Minh, T.D.C.; Blake, D.R.; Galassetti, P.R. The clinical potential of exhaled breath analysis for diabetes mellitus. Diabetes Res. Clin. Pract. 2012, 97, 195-205. [CrossRef] [PubMed]

23. Karyakin, A.A.; Nikulina, S.V.; Vokhmyanina, D.V.; Karyakina, E.E.; Anaev, E.K.H.; Chuchalin, A.G. Non-invasive monitoring of diabetes through analysis of the exhaled breath condensate (aerosol). Electrochem. Commun. 2017, 83, 81-84. [CrossRef]

24. Righettoni, M.; Tricoli, A.; Pratsinis, S.E. Si: $\mathrm{WO}_{3}$ Sensors for highly selective detection of acetone for easy diagnosis of diabetes by breath analysis. Anal. Chem. 2010, 82, 3581-3587. [CrossRef] [PubMed]

25. WHO (World Health Organization). Global Report on Diabetes. Available online: http://www.who.int/ diabetes/en/ (accessed on 12 June 2018).

26. Rydosz, A. A negative correlation between blood glucose and acetone measured in healthy and type-1 diabetes mellitus patient breath. J. Diabetes Sci. Technol. 2015, 9, 881-884. [CrossRef] [PubMed]

27. Amann, A.; Smith, D. Volatile Biomarkers. In Non-Invasive Diagnosis in Physiology and Medicine; Elsevier: New York, NY, USA, 2013.

28. FIGARO. TGS 822-Product Information. Available online: www.figarosensor.com/products /822pdf.pdf (accessed on 12 June 2018).

29. Lee, J.; Lim, S.-H. CNT Foam-Embedded Micro Gas Preconcentrator for Low-Concentration Ethane Measurements. Sensors 2018, 18, 1547. [CrossRef] [PubMed]

30. Sun, X.; He, J.; Yang, X. Human breath as a source of VOCs in the built environment, Part I: A method for sampling and detection species. Build. Environ. 2017, 125, 565-573. [CrossRef]

31. Eranna, G. Metal Oxide Nanostructures as Gas Sensing Devices; CRC Press: Boca Raton, FL, USA, 2011.

32. Zhu, L.; Zeng, W. Room-temperature gas sensing of ZnO-based gas sensor: A review. Sens. Actuators A Phys. 2017, 267, 242-261. [CrossRef]

33. Li, Z.; Liu, Y.; Guo, D.; Guo, J.; Su, Y. Room-temperature synthesis of CuO/reduced graphene oxie nanohybrids for hgih-performance $\mathrm{NO}_{2}$ gas sensor. Sens. Actuators B 2018, 271, 306-310. [CrossRef]

34. Evans, G.P.; Powell, M.J.; Johnson, I.D.; Howard, D.P.; Bauer, D.; Darr, J.A.; Parking, I.P. Room temperature vanadium dioxide-carbon nanotube gas sensos via continuous hydrothermal flow synthesis. Sens. Actuators B 2018, 255, 1119-1129. [CrossRef]

35. Hijazi, M.; Rieu, M.; Stambouli, V.; Tournier, G.; Viricelle, J.-P.; Pijolat, C. Ambiet temperature selective ammonia gas sensor based on $\mathrm{SnO}_{2}$-APTES modificiations. Sens. Actuators B 2018, 256, 440-447. [CrossRef]

36. Rydosz, A.; Maciak, E.; WIncza, K.; Gruszczynski, S. Microwave-based sensors with phthalocyanine films for acetone, ethanol and methanol detection. Sens. Actuators B 2016, 237, 876-886. [CrossRef]

37. Staszek, K.; Rydosz, A.; Maciak, E.; Wincza, K.; Gruszczynski, S. Six-port microwave system for volatile organic compounds detection. Sens. Actuators B 2017, 245, 882-894. [CrossRef]

38. Li, J.; Smeeton, T.M.; Zanola, M.; Barrett, J.; Berryman-Bousquet, V. A compact breath acetone analyzer based on an ultraviolot light emitting diode. Sens. Actuators B Chem. 2018, 273, 76-82. [CrossRef]

39. Gao, L.; Yang, X.; Chen, X.; Wang, J. Ionic liquid-based slab optical waveguide sensor for the detection of ammonia in human breath. J. Colloid Interface Sci. 2018, 512, 819-825. [CrossRef] [PubMed]

40. Bratu, A.M.; Petrus, M.; Popa, C. Laser-based spectrometer for opitcal trace gas detection in young adults with autism. Microchem. J. 2018, 138, 203-208. [CrossRef]

41. Rydosz, A.; Szkudlarek, A.; Ziabka, M.; Domanski, K.; Maziarz, W.; Pisarkiewicz, T. Performance of Si-doped $\mathrm{WO}_{3}$ thin films for acetone sensing prepared by glacing angle DC magnetron sputtering. IEEE Sens. J. 2016, 16, 1004-1012. [CrossRef]

42. Hu, J.; Yang, J.; Wang, W.; Xue, Y.; Sun, Y.; Li, P.; Lian, K.; Zhang, W.; Chen, L.; Shi, J.; et al. Synthesis and gas sensing properties of $\mathrm{NiO} / \mathrm{SnO}_{2}$ herarchical structures toward ppb-level acetone detection. Mater. Res. Bull. 2018, 102, 294-303. [CrossRef] 
43. Hu, J.; Zou, C.; Su, Y.; Li, M.; Yang, Z.; Ge, M.; Zhang, Y. One-step synthesis of $2 \mathrm{D} \mathrm{C}_{3} \mathrm{~N}_{4}$-tin oxide gas sensors for enhanced acetone vapor detection. Sens. Actuators B 2017, 253, 641-651. [CrossRef]

44. Kalidoss, R.; Umapathy, S.; Sibalingam, Y. An investigation of $\mathrm{GO}-\mathrm{SnO}_{2}-\mathrm{TiO}_{2}$ ternary nanocomposite for the detection of acetone in diabetes mellitus patient's breath. Appl. Surf. Sci. 2018, 449, 677-684. [CrossRef]

45. Tomer, V.K.; Singh, K.; Kaur, H.; Shorie, M.; Sabherwal, P. Rapid acetone detection using indium loaded $\mathrm{WO}_{3} / \mathrm{SnO}_{2}$ nanohybrid sensor. Sens. Actuators B 2017, 253, 703-713. [CrossRef]

46. Asgari, M.; Saboor, F.H.; Mortazavi, Y.; Khodadadi, A.K. $\mathrm{SnO}_{2}$ decorated $\mathrm{SiO}_{2}$ chemical sensors: Enhanced sensing performance toward ethanol and acetone. Mater. Sci. Semicond. Proccess. 2018, 68, 87-96. [CrossRef]

47. Li, Y.; Hua, Z.; Zeng, Y.; Qiu, Z.; Tian, X.; Wang, M.; Li, E. Modified impregnation synthesis of Ru-loaded $\mathrm{WO}_{3}$ nanoparticles for acetone sensing. Sens. Actuators B 2018, 265, 249-256. [CrossRef]

48. Kim, D.-H.; Jang, J.-S.; Koo, W.-T.; Choi, S.-J.; Kim, S.-J.; Kim, I.-D. Hierarchically interconnected porosity control of catalyst-loaded $\mathrm{WO}_{3}$ nanofiber scaffold: Superior acetone sensing layers for exhaled breath analysis. Sens. Actuators B 2018, 259, 616-625. [CrossRef]

49. Chen, L.; Huang, L.; Lin, Y.; Sai, L.; Chang, Q.; Shi, W.; Chen, Q. Fully gravure-printed $\mathrm{WO}_{3} /$ Pt-decorated rGO nanosheets composite film for detection of acetone. Sens. Actuators B 2018, 255, 1482-1490. [CrossRef]

50. Shen, J.-Y.; Wang, M.-D.; Wang, Y.-F.; Hu, J.-Y.; Zhu, Y.; Zhang, Y.X.; Li, Z.-J.; Yao, H.-C. Iron and carbon codoped $\mathrm{WO}_{3}$ with hierarchical walnut-like microstructure for highly sensitive and selective acetone sensor. Sens. Actuators B 2018, 256, 27-37. [CrossRef]

51. Bartsch, H.; Stoepel, D.; Mueller, J.; Rydosz, A. Printed heater elements for smart sensor packages in LTCC. In Proceedings of the 2017 21st European Microelectronics and Packaging Conference (EMPC) \& Exhibition, Warsaw, Poland, 10-13 September 2017. [CrossRef]

52. Wang, X.-F.; Ma, W.; Jiang, F.; Cao, E.-S.; Sun, K.-M.; Cheng, L.; Song, X.-Z. Prussian Blue analogue derived prorous $\mathrm{NiFe}_{2} \mathrm{O}_{4}$ nanocubes for low-concentration acetone sensing at low working temperature. Chem. Eng. J. 2018, 338, 504-512. [CrossRef]

53. Park, $\mathrm{S}$. Acetone gas detection using $\mathrm{TiO}_{2}$ nanoparticles functionalized $\mathrm{In}_{2} \mathrm{O}_{3}$ nanowires for diagnosis of diabetes. J. Alloy Compd. 2017, 696, 655-662. [CrossRef]

54. Liu, X.; Tian, X.; Jiang, X.; Jiang, L.; Hiu, P.; Zhang, S.; Sun, X.; Yang, X.; Cao, R.; Xu, X. Facile preparation of hierarchical Sb-doped $\mathrm{In}_{2} \mathrm{O}_{3}$ microstructures for acetone detection. Sens. Actuators B 2018, 270, $304-311$. [CrossRef]

55. Wongrat, E.; Chanlek, N.; Chueaiarrom, C.; Thupthimchun, W.; Samransuksamer, B.; Choopun, S. Acetone gas sensors based on $\mathrm{ZnO}$ nanostructures dectorated with $\mathrm{Pt}$ and $\mathrm{Nb}$. Ceram. Int. 2017, 43, S557-S566. [CrossRef]

56. Kollbek, K.; Szkudlarek, A.; Klejna, S.; Rydosz, A. Electronic sensitization of CuO thin films by Cr-doping for enhanced gas sensor response at low detection limit. J. Mater. Chem. C 2018. under review.

57. Wang, X.; Qin, H.; Pei, J.; Chen, Y.; Li, L.; Xie, J.; Hu, J. Sensing performances to low concentration acetone for palladium doped $\mathrm{LaFeO}_{3}$ sensors. J. Rare Earths 2016, 34, 704-710. [CrossRef]

58. Ma, R.-J.; Li, G.-D.; Zou, X.; Gao, R.; Chen, H.; Zhao, X. Bimetallic Pt-Au nanocatalysts decorated $\operatorname{In}_{2} \mathrm{O}_{3}$ nests composed of ultrathin nanosheets for type 1 diabetes diagnosis. Sens. Actuators B 2018, 270, $247-255$. [CrossRef]

59. Li, X.; Lu, D.; Shao, C.; Lu, G.; Li, X.; Liu, Y. Hollow $\mathrm{CuFe}_{2} \mathrm{O}_{4} / \alpha-\mathrm{Fe}_{2} \mathrm{O}_{3}$ composite with ultrathin porous shell for acetone detection at ppb levels. Sens. Actuators B 2018, 258, 436-446. [CrossRef]

60. Zjang, L.; Dong, B.; Xu, L.; Zhang, X.; Chen, J.; Sun, X.; Xu, H.; Zhang, T.; Bai, X.; Zhang, S.; et al. Three-dimensional ordered $\mathrm{ZnO}-\mathrm{Fe}_{2} \mathrm{O}_{4}$ inverse opal gas sensors toward trace concentration acetone detection. Sens. Actuators B 2017, 252, 367-374.

61. ZXiong, Y.; Zhu, Z.; Ding, D.; Lu, W.; Xue, Q. Multi-shelled $\mathrm{ZnCO}_{2} \mathrm{O}_{4}$ yolk-shell spheres for high-performance acetone gas sensor. Appl. Surf. Sci. 2018, 443, 114-121.

62. Zhang, Z.; Zhu, L.; Wen, Z.; Ye, Z. Controllable synthesis of $\mathrm{Co}_{3} \mathrm{O}_{4}$ crossed nanosheet arrays toward an acetone gas sensor. Sens. Actuators B 2017, 238, 1052-1059. [CrossRef]

63. Hao, X.; Wang, B.; Ma, C.; Liu, F.; Yang, X.; Liu, T.; Liang, X.; Yang, C.; Zhu, H.; Lu, G. Mixed potential type sensor based on stabilized zirconia and $\mathrm{Co}_{1-x} \mathrm{Zn}_{\mathrm{x}} \mathrm{Fe}_{2} \mathrm{O}_{4}$ sensing electrode for detection of acetone. Sens. Actuators B 2018, 255, 1173-1181. [CrossRef] 
64. Chen, N.; Li, Y.; Deng, D.; Liu, X.; Xing, X.; Xiao, X.; Wang, Y. Acetone sensing performances based on nanoporous $\mathrm{TiO}_{2}$ synthesized by a facile hydrothermal method. Sens. Actuators B 2017, 238, 491-500. [CrossRef]

65. Yang, C.-M.; Chen, T.-C.; Yang, Y.-C.; Hsiao, M.-C.; Meyyappan, M.; Lai, C.-S. Ultraviolet illumination effect on monolayer graphene-based resistive sensor for acetone detection. Vacuum 2017, 140, 89-95. [CrossRef]

66. Yang, C.-M.; Chen, T.-C.; Yang, Y.-C.; Meyyappan, M.; Lai, C.-S. Enhanced acetone sensing properties of monolayer graphene at room temperatue by electrode spacing effect and UV illumination. Sens. Actuators $B$ 2017, 253, 77-84. [CrossRef]

67. Zhang, H.; Qin, H.; Zhang, P.; Chen, Y.; Hu, J. Low concentration acetone gas sensing properties of $3 \mathrm{wt}$ $\%$ Pd-doped $\mathrm{SmCo}_{x} \mathrm{Fe}_{1-\mathrm{x}} \mathrm{O}_{3}$ nanocrystalline powders under UV light ilumination. Sens. Actuators B 2018, 260, 33-41. [CrossRef]

68. Ye, M.; Chien, J.; Toma, K.; Arakawa, T.; Mitsubayashi, K. An acetone bio-sniffer (gas phase biosensor) enabling assessment of lipid metabolism from exhaled breath. Biosens. Bioelectron. 2015, 73, $203-213$. [CrossRef] [PubMed]

69. Teshima, N.; Li, J.; Toda, K.; Dasgupta, P.K. Determination of acetone in breath. Anal. Chim. Acta 2005, 535, 189-199. [CrossRef]

70. Cho, S.M.; Kim, Y.J.; Heo, G.S.; Shin, S.-M. Two-step preconcentration for analysis of exhaled gas of human breath with electronic nose. Sens. Actuators B 2006, 117, 50-57. [CrossRef]

71. Ueta, I.; Saito, Y.; Hosoe, M.; Okamoto, M.; Ohkita, H.; Shirai, S.; Tamura, H.; Jinno, K. Breath acetone analysis with miniaturized sample preparation device: In-needle preconcentration and subsequent determination by gas chromatography-mass spectrometry. J. Chromatogr. B 2009, 877, 2551-2556. [CrossRef] [PubMed]

72. Groves, W.A.; Zellers, E.T.; Frye, G.C. Analyzing organic vapors in exhaled breath using a surface acoustic wave sensor array with preconcentration: Selection and characterization of the preconentrator adsorbent. Anal. Chim. Act. 1998, 371, 131-143. [CrossRef]

73. Li, M.; Biswas, S.; Nantz, M.H.; Higashi, R.M.; Fu, X.A. A microfabricated preconcentration device for breath analysis. Sens. Actuators B 2013, 180, 130-136. [CrossRef]

74. Rydosz, A.; Maziarz, W.; Pisarkiewicz, T.; Domanski, K.; Grabiec, P. A gas micropreconcentrator for low level acetone measurements. Microelectron. Reliab. 2012, 52, 2640-2646. [CrossRef]

75. Rydosz, A. Micropreconcentrators in silicon-glass technology for the detection of diabetes biomarkers. J. Microelectr. Electr. Compon. Mater. 2014, 44, 126-136.

76. Rydosz, A.; Maziarz, W.; Pisarkiewicz, T.; Bartch de Torres, H.; Mueller, J. Amicropreconcentrator design using low temperature cofired ceramics technology for acetone detection applications. IEEE Sens. J. 2013, 13, 1889-1896. [CrossRef]

77. Rydosz, A.; Wincza, K.; Gruszczynski, S. Microsystem in LTCC for the Detection of Acetone in Healthy and Diabetes Breath. In Proceedings of the 2016 IEEE ANDESCON Conference, Arequipa, Peru, 19-21 October 2016.

78. Rydosz, A. Micropreconcentrator in LTCC technology with mass spectrometry for the detection of acetone in healthy and type-1 diabetes mellitus patient breath. Metabolities 2014, 4, 921-931. [CrossRef] [PubMed]

79. Chuang, M.-Y.; Lin, Y.-T.; Tung, T.-W.; Chang, L.-Y.; Zan, H.-W.; Meng, H.-F.; Lu, C.-J.; Tao, Y.-T. Room-temperature-operated organic-based acetone gas sensor forbreath analysis. Sens. Actuators B 2018, 260, 593-600. [CrossRef]

80. Wang, C.; Sahay, P. Breath analysis using laser spectroscopic techniques: Breath biomarkers, spectral fingerprints, and detection limits. Sensors 2009, 9, 8230-8262. [CrossRef] [PubMed]

81. Schwoebel, H.; Schubert, R.; Sklorz, M.; Kischkel, S.; Zimmermann, R.; Schubert, J.K.; Miekisch, W. Phase-resolved real-time breath analysis during exercise by means of smart processing of PTR-MS data. Anal. Bioanal. Chem. 2011, 401, 2079-2091. [CrossRef] [PubMed]

82. Toshiba Develops Breath Analyzer for Medical Applications. Available online: https://www.toshiba.co.jp/ about/press/2014_03/pr1801.htm (accessed on 16 July 2018).

83. Tranchito, L.; Gul, Z.; Cikach, F.; Shrestha, K.; Dweik, R.; Tang, W.H.W. Reduction in Exhaled Acetone Tracks with Weight Loss Following Diuretic Therapy in Acute Decompensated Heart Failure. J. Card Fail. 2013, 19, S10. [CrossRef] 
84. Yokokawa, T.; Sugano, Y.; Shimouchi, A.; Shibata, A.; Nakayama, T.; Ohara, T.; Jinno, N.; Kanzaki, H.; Anzai, T. A case of acute decompensated heart failure evaluated by series of exhaled acetone concentrations as noninvasive biomarker of heart failure severity. Int. J. Cardiovasc. 2016, 204, 112-113. [CrossRef] [PubMed]

85. Saasa, V.; Malwela, T.; Beukes, M.; Mokgotho, M.; Liu, C.-P.; Mwakikunga, B. Sensing Technologies for Detection of Acetone in Human Breath for Diabetes Diagnosis and Monitoring. Diagnostics 2018, 8, 12. [CrossRef] [PubMed]

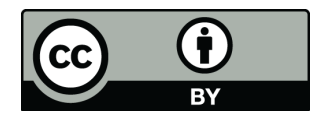

(C) 2018 by the author. Licensee MDPI, Basel, Switzerland. This article is an open access article distributed under the terms and conditions of the Creative Commons Attribution (CC BY) license (http://creativecommons.org/licenses/by/4.0/). 